\title{
The analysis of occupational accidents among the healthcare staffs
}

\author{
Songül Özenir ${ }^{1} \odot$, Vesile Ünver ${ }^{2} \odot$ \\ ${ }^{1}$ Department of Nursery, Tuzla State Hospital, Istanbul, Turkey \\ ${ }^{2}$ Department of Nursery, Acıbadem Mehmet Ali Aydinlar University, Faculty of Health Sciences, Istanbul, Turkey
}

\begin{abstract}
Objectives: The aim of the study is to identify the attitudes of healthcare professionals towards the potential occupational accidents and the safe use of sharp instruments in their work environment.

Methods: The study was carried out between February 2017 and March 2017 with the participation of 173 health care personnel. The data collection forms consist of two parts, "Questionnaire about the occupational accidents that the participants might experience" and the"Attitude scale about the safe use of sharp objects and instruments by the participants".

Results: The number of injuries they experienced in the same period varied between 1 and 12 and the mean injury cases were found to be $2.76 \pm 2.59$. The total score of the participants from the Attitude scale was found to vary between 68 and 112 , with a mean total score of $81.65 \pm 7.03$.

Conclusions: The participants of the study are subject to serious occupational accidents and occupations risks which may negatively affect their health.

Keywords: Healthcare workers, occupational injuries, sharp objects and instruments
\end{abstract}

H ospitals are defined as high risk working areas. Some of the risks they face include the inevitable contact with sick people or their blood and other body fluid. Therefore, they are subject to several occupational accidents due to the working conditions $[1,2]$.

Healthcare professionals are $12 \%$ of the total working population in the world [3]. In Turkey, there were 787,352 healthcare professionals in 2015 [4]. As it is well known that healthcare professionals try to care about other people's health and treat them without thinking about their health in a self-sacrificing manner and they are subject to serious threats which may lead to many negative effects in their life.

Hospitals have much more complex structures in contrast to many other work settings. In such a complex structure, healthcare professionals may be subject to both traditional occupational dangers such as musculoskeletal system illness (i.e. backache or neck ache), stress, and more specific and much riskier health problems, including sharps injuries, radiation exposure, latex allergy $[5,6]$. In comparison to other professionals, healthcare professionalsare reported to experience musculoskeletal system pain much more frequently. On the other hand, such health problems are common among healthcare professionals and they are also subject to infections transmitted by blood such as Hepatitis B (HBV), Hepatitis C (HCV), and Human Immunodeficiency Virus (HIV) as a result of injuries caused by sharp instruments $[6,7]$. 
Healthcare staff is subject to numerous risks of getting an infection in their work environment. Such infections mostly occur through contact with blood and other body fluids [2]. Such diseases, that are the results of contact with blood and other body fluids, have higher rates of morbidity and mortality and occur frequently due to the injuries caused by sharp objects or instruments and percutaneous injuries $[2,8]$.

The data reported by the Centers for Disease Control and Prevention (CDC) indicate that healthcare professionals in the USA experience the injuries caused by needle tip and percutaneous injuries of which the number increases each year and that the yearly cases of the injuries caused by injectors among healthcare professionals are 385,000 and the daily mean of the injuries caused by sharp instruments is 1,000 [9]. The World Health Organization (WHO) reported that each year in Europe, nearly 304,000 healthcare professionals are diagnosed with HBV, 149,000 healthcare professionals are diagnosed with $\mathrm{HCV}$ and 22,000 healthcare professionals are diagnosed with HIV due to the injuries caused by sharp objects and instruments [10]. The findings of a meta-analysis suggest that the frequency of the HCV infection is much higher among healthcare professionals in contrast to the general population [11].

The findings of the CDC suggest that the injuries caused by contact with blood and body fluids occur due to percutaneous injuries $(82 \%)$, in inpatient treatment sections (36\%) and operating theatres $(29 \%)$. The contact with blood and body fluids has been observed mostly among nurses, physicians and technicians $(42 \%, 30 \%$, and $15 \%$, respectively) [12].

In the health sector, there are more occupational accidents and injuries, but the reporting of these cases is not so common. For instance, in the European health sector, the rate of occupational accidents is $34 \%$ more than those in other professional sectors [9]. The rate of reporting occupational accidents and injuries varies from one country to another. The findings of the CDC indicate that the rate of reporting the injuries caused by sharp instruments is about $46 \%$ and that those reported such cases are technicians $(66 \%)$, nurses $(53 \%)$, physicians (53\%) and surgeons (30\%) [13]. In a study carried out in India which covered the period between September 2012 and August 2014, it was found that there were 401 cases involving the contact with blood and body fluids by healthcare professionals and 208 cases were reported among them (52\%). Those who reported such cases included physicians $(77.5 \%$, $93 / 120)$, nurses (42.1\%) and laboratory technicians (25\%) [9]. A study conducted in Turkey concluded that the rate of reporting such incidents is just $12.7 \%$ [12]. In Turkey, a regulation named "Patient and Employee Safety Regulation" was issued to establish safety committees at hospitals and to identify the necessary steps to be taken [14]. However, there are no data concerning the healthcare staff who experienced occupational accidents, how many of them became incapable of working or died and the specifics of the working conditions in the health sector in Turkey [9].

All these figures given above suggest that one of the serious threats caused as a result of the occupational accidents is the injury occurred during the use of sharp instruments and contact with blood and other types of bodily fluids. Therefore, it is significant to be informed about the attitudes of healthcare professionals towards the use of sharp instruments in their work environment. This study was carried out to identify the attitudes of healthcare professionals towards potential occupational accidents and the safe use of sharp instruments in their work environment. The data of the study are thought to be useful in improving the health of healthcare staff and in developing and shaping the related policies.

\section{METHODS}

\section{Subjects}

The study targeted healthcare professionals working at a public hospital during the period between February 2017 and March $2017(\mathrm{n}=191)$. There were 51 physicians, 83 nurses/midwives/healthcare staff, 11 X-ray technicians, 7 anesthesia technicians, 8 laboratory technicians, 5 pharmacists, 2 audiologists and 24 medical secretaries/public servants. There was no specific sampling method used in the study. Instead, all of the healthcare professionals whose characteristics given above were attempted to be includedin the study. The participants of the study were 173 healthcare professionals who volunteered to take part in the study. The others did not volunteer or were not working at the hospital during the specified period due to several reasons (being on leave, being on sick leave, etc.). The participants represent $91 \%$ of 
the targeted sample.

\section{Data Collection}

The data of the study were collected through questionnaires performed by one of the authors; the participants were informed about the study before the application. The questionnaires were administered at the related divisions where the participants were working at. The administration of the questionnaires lasted about 25 minutes.

\section{Data Collection Form}

The data collection form included two sections, which are given as follows:

-A questionnaire which included items about the occupational accidents that the participants might experienced

-An attitude scale about the safe use of the sharp objects and instruments by the participants

Questionnaire about the occupational accidents that the participants might experienced:

The questionnaire administered to the participants is composed of two sections. The first one included a total of eleven items about the socio-demographical characteristics of the participants, such as age, gender, marital status, educational background and their roles at the hospital as well as other specific information about their profession at the hospital.The second section includes nineteen items that were concerned with the occupational accidents that the participants experienced in the past. One of the items in this section, namely "Please indicate your status in terms of Hepatitis B", was not endorsed by the hospital where the participants were working at. Therefore, it was reworded as the following and endorsed by the hospital.

"Item 19. Do you know your status in terms of Hepatitis B? Yes (--) No (--)"

Attitude scale about the safe use of the sharp objects and instruments by the participants:

The validity and reliability analysis of the attitude scale about the safe use of the sharp objects and instruments was carried out by Uzunbayir [15], and the Cronbach's alpha coefficient of the scale was found to be 0.80 . In the current study, the Cronbach's alpha coefficient of the scale was found to be 0.822 .
The scale is a 5-point Likert-type scale. It includes twenty-five items about the views of the healthcare professionals concerning the safe use of the sharp objects and instruments. The potential answers to the positive statements in the scale are as follows: 1) Strongly agree (5 points), 2) Agree (4 points), 3) No idea (3 points), 4) Disagree (2 points), and 5) Strongly disagree (1 point).

The potential answers to the negatively stated items are as follows: 1) Strongly agree (1 point), 2) Agree (2 points), 3) No idea (3 points), 4) Disagree (4 points), and 5) Strongly disagree (5 points).

The scale has three subdimensions: cognitive, affective and behavioral. For the score of the cognitive scale, the following items are taken into consideration: $1,4,8,11,13,16,18,19,20,23,24$ and 25 . The maximum score from the cognitive sub-dimension is 60 , while the minimum score is 12 . For the score of the affective scale, the following items are taken into consideration: $2,7,9,10,14$ and 22 . The maximum score from the affective sub-dimension is 30 , while the minimum score is 6 . For the score of the behavioral scale, the following items are taken into consideration: $3,5,6,12,15,17$ and 21 . The maximum score from the affective sub-dimension is 35 , while the minimum score is 7 .

\section{Ethical issues}

In order to carry out the study, ethical permissions were received from Acıbadem Mehmet Aydınlar University through Acibadem Healthcare Institutions' Medical Research Ethics committee dated 24.11.2016 and numbered 2016/19 and from the Ministry of Health through its Public Hospitals' General Directorate's Istanbul Province Anatolian South region Public Hospitals Association General Secretariat dated 07.02.2017 and numbered 35778018774.99 .

\section{Statistical Analysis}

For the statistical analysis of the data, the SPSS software was used. The normality of the data distribution was analyzed by the Shapiro Wilk test. The analysis showed that the data had a normal distribution. The data were analyzed using both the descriptive statistics (means, standarddeviation, frequency) and t-test which was employed to make comparisons between two groups. The ANOVA test was used to make comparisons among the groups 
more than two. The correlations among the data were analyzed through the Pearson correlation analysis. The significance level was set at $p<0.05$.

\section{RESULTS}

The age of the participants varied between 23 years and 62 years and the mean age of them was $38.32 \pm 7.82$. It was also found that $31 \%$ of the participants were either 34 years or younger $(n=35)$, $24.3 \%$ of them were between the age group of 35 and $39,26.6 \%$ of them were between the age group of 40 44 and $17.3 \%$ were either 45 yeras or older. Most of the participants were female $(60.1 \% ; \mathrm{n}=104)$ and married $(75.1 \% ; n=130)$. Concerning the educational background, it was found that $32.4 \%$ of them had a two-year higher education $(\mathrm{n}=56)$. Among the participants, $47.4 \%$ were either nurses or midwives (n $=82$ ). The period of working at the units of the participants was found to vary between 0.5 year and 30 years, with the mean period of $5.38 \pm 4.99$. The professional experience of the participants was found to vary between 0.5 year and 37 years, with the mean period of $14.74 \pm 8.11$. The weekly working hours of the participants varied between 35 hours and 100 hours with the mean hour of $45.14 \pm 8.85$. The rate of the participants who worked at outpatient clinics was found to be $27.2 \%(n=47)$. It was also found that $74.6 \%$ of the participants had night shifts at their respective units $(n=129)$.

Table 1 shows the occupational accidents that the participants experienced in the last year. It is seen that $18.2 \%$ of them had injuries caused by a sharp object or instrument $(n=32)$ and that $23.3 \%$ of them contacted with the body fluids of the patients they

Table 1. Occupational accidents experienced by the participants in the last year

\begin{tabular}{|c|c|}
\hline Occupational accidents & Data \\
\hline \multicolumn{2}{|l|}{ Injuries caused by sharp objects and instruments, $\mathrm{n}(\%)$} \\
\hline Yes & $32(18.2)$ \\
\hline No & $144(81.8)$ \\
\hline \multicolumn{2}{|l|}{ Contact with the body fluids of patients, $n(\%)$} \\
\hline Yes & $41(23.3)$ \\
\hline No & 135 (76.7) \\
\hline \multicolumn{2}{|l|}{ Both injuries by sharp instruments and contact with the body fluids of patients, $n(\%)$} \\
\hline Yes & $57(32.9)$ \\
\hline No & $116(67.1)$ \\
\hline \multicolumn{2}{|l|}{ Reasons for injuries $(\mathrm{n}=57), \mathrm{n}(\%)$} \\
\hline Taking medicine from an ampoule & $12(21.1)$ \\
\hline Separating pinpoint from an injector & $9(15.8)$ \\
\hline Recapping the pinpoint & $5(8.8)$ \\
\hline During subcutaneous medicine practices & $5(8.8)$ \\
\hline While taking suture & $5(8.8)$ \\
\hline During surgery and medical dressing & $5(8.8)$ \\
\hline During disposal & $5(8.8)$ \\
\hline IV set and branule insertion & $3(5.3)$ \\
\hline IV medicationadministration & $1(1.8)$ \\
\hline While bending the needle & $1(1.8)$ \\
\hline Taking blood from the patients & $1(1.8)$ \\
\hline The number of injuries by sharp objects and instruments, mean \pm SD (min-max) & $2.76 \pm 2.59(2-12)$ \\
\hline
\end{tabular}


Table 2. Practices followed by the participants after the occupational accidents

\begin{tabular}{lc}
\hline Practices performed following the occupational accident & Data \\
\hline Practices following the injury $(\mathrm{n}=57), \mathrm{n}(\%)$ & $36(63.2)$ \\
Washing with an antiseptic solution & $20(35.1)$ \\
Having a medical inspection & $16(28.1)$ \\
Informing the unit responsibleabout the incident & $12(21.1)$ \\
\hline Filling the report form about the case & $3(5.3)$ \\
Taking prophylactic medicine & $2(3.5)$ \\
Vaccination & $1(1.8)$ \\
Having an Ig & $37(21.0)$ \\
Reporting the accident, $\mathrm{n}(\%)$ & $139(79.0)$ \\
Yes & \\
No & $28(75.7)$ \\
\hline Unit/persons informed through a report, $\mathrm{n}(\%)$ & $9(24.3)$ \\
\hline Occupational health and safety unit & $7(18.9)$ \\
\hline
\end{tabular}

treated $(\mathrm{n}=41)$.

Table 2 shows that following the injury cases $63.2 \%$ of the participants wash the injured part with antiseptic solution $(\mathrm{n}=36), 35.1 \%$ of them apply for medical investigation $(n=20), 28.1 \%$ of them inform the unit responsible about the incident $(\mathrm{n}=16), 21.1 \%$ of them fill the incident report form $(\mathrm{n}=12), 5.3 \%$ of them take prophylactic drug $(\mathrm{n}=3), 3.5 \%$ of themvaccinate $(\mathrm{n}=2)$ and $1.8 \%$ of them have an IG $(\mathrm{n}=1)$. It was found that the rate of the participants who reported occupational accidents is $21 \%(\mathrm{n}=37)$. Of them, $75.7 \%$ report the incident to infection control nurses $(n=28), 24.3 \%$ report it to the occupational health safe unit $(\mathrm{n}=9)$ and $18.9 \%$ report it to the unit responsible $(n=7)$. It was found that $32.9 \%$ of the participants experienced either an injury case caused by a sharp object or instrument or was subject to contact with the body fluid in the last year $(n=57)$. The average injury rate to the average weekly working hours of nurses (45.14) was found to be 1.32.

Table 3 shows the scores of the participants from the attitude scale for the safe use of sharp objects and instruments by healthcare professionals based on the subdimensions of the scale. Their scores from the cognitive subdimension vary between 32 and 56, and their mean score was found to be $42.92 \pm 3.73$. The scores of the participants from the affective subdimension of the scale were found to vary between 15 and 29 with a mean of $21.55 \pm 2.46$. It was found that the scores of the participants from the behavioral subdimension of the scale were between 7 and 28, and the mean score was $17.17 \pm 3.13$. The total score of the participants from the scale was found to vary between 68 and 112, with a mean total score of 81.65

Table 3. Scores of the participants from the attitude scale about the safe use of sharp objects and instruments, and subdimensions $(n=173)$

\begin{tabular}{lcc}
\hline Sub-categories of the scale & Minimum-Maximum scores & Mean \pm SD \\
\hline Cognitive & $32-56$ & $42.92 \pm 3.73$ \\
Affective & $15-29$ & $21.55 \pm 2.46$ \\
Behavioral & $7-28$ & $17.17 \pm 3.13$ \\
Total & $68-112$ & $81.65 \pm 7.03$ \\
\hline
\end{tabular}


Table 4. Comparison of the scores of the participants from the attitude scale and subdimensions based on some variables

\begin{tabular}{|c|c|c|c|c|c|}
\hline Socio-demographical & & Cognitive & Affective & Behavioral & Total \\
\hline \multirow[t]{6}{*}{ Age group } & $<35$ & $42.44 \pm 3.05$ & $21.58 \pm 2.48$ & $16.84 \pm 2.83$ & $80.85 \pm 5.33$ \\
\hline & $36-39$ & $43.31 \pm 3.69$ & $21.6 \pm 2.49$ & $17.00 \pm 3.51$ & $81.9 \pm 7.37$ \\
\hline & $40-44$ & $43.22 \pm 3.89$ & $21.57 \pm 2.29$ & $17.76 \pm 3.39$ & $82.54 \pm 8.07$ \\
\hline & $\geq 45$ & $42.83 \pm 4.65$ & $21.43 \pm 2.75$ & $17.13 \pm 2.67$ & $81.4 \pm 7.76$ \\
\hline & $\mathrm{F}$ & 0.559 & 0.030 & 0.795 & 0.509 \\
\hline & $p$ value & 0.643 & 0.993 & 0.498 & 0.677 \\
\hline \multirow[t]{4}{*}{ Gender } & Female & $42.63 \pm 3.11$ & $21.3 \pm 2.5$ & $17.03 \pm 2.69$ & $80.96 \pm 5.6$ \\
\hline & Male & $43.36 \pm 4.5$ & $21.94 \pm 2.37$ & $17.39 \pm 3.71$ & $82.7 \pm 8.71$ \\
\hline & $\mathrm{F}$ & -1.258 & -1.695 & -0.745 & -1.595 \\
\hline & $p$ value & 0.210 & 0.092 & 0.457 & 0.113 \\
\hline \multirow[t]{4}{*}{ Marital status } & Married & $43.15 \pm 3.9$ & $21.51 \pm 2.56$ & $17.15 \pm 3.27$ & $81.81 \pm 7.46$ \\
\hline & Single & $42.26 \pm 3.09$ & $21.7 \pm 2.16$ & $17.23 \pm 2.69$ & $81.19 \pm 5.58$ \\
\hline & $\mathrm{F}$ & 1.360 & -0.438 & -0.143 & 0.501 \\
\hline & $p$ value & 0.176 & 0.662 & 0.887 & 0.617 \\
\hline \multirow[t]{5}{*}{$\begin{array}{l}\text { Educational } \\
\text { background }\end{array}$} & $\begin{array}{l}\text { Two-year university } \\
\text { education or less }\end{array}$ & $42.87 \pm 4.63$ & $21.91 \pm 2.63$ & $17.6 \pm 3.34$ & $82.38 \pm 8.54$ \\
\hline & Undergraduate & $42.62 \pm 2.72$ & $21.17 \pm 2.34$ & $17.04 \pm 2.9$ & $80.83 \pm 5.01$ \\
\hline & Graduate & $43.39 \pm 2.94$ & $21.39 \pm 2.25$ & $16.59 \pm 2.96$ & $81.36 \pm 6.1$ \\
\hline & $\mathrm{F}$ & 0.521 & 1.538 & 1.526 & 0.802 \\
\hline & $p$ value & 0.595 & 0.218 & 0.220 & 0.450 \\
\hline \multirow[t]{5}{*}{ Profession } & Nurse/midwife & $42.99 \pm 3.31$ & $21.22 \pm 2,23$ & $17.27 \pm 2.86$ & $81.48 \pm 6.11$ \\
\hline & Physician & $43.31 \pm 2.63$ & $21.48 \pm 2,47$ & $16.26 \pm 2.24$ & $81.05 \pm 5.4$ \\
\hline & Other & $42.49 \pm 5.02$ & $22.18 \pm 2,74$ & $17.8 \pm 3.98$ & $82.47 \pm 9.4$ \\
\hline & $\mathrm{F}$ & 0.565 & 2,424 & 2,848 & 0,509 \\
\hline & $p$ value & 0.569 & 0,092 & 0,061 & 0,602 \\
\hline \multirow[t]{10}{*}{ Working unit } & Policlinic & $42.66 \pm 3.15$ & $21.15 \pm 2.34$ & $16.36 \pm 2.98$ & $80.17 \pm 5.78$ \\
\hline & Emergency unit & $43.7 \pm 3.44$ & $21.65 \pm 2.02$ & $17.19 \pm 2.94$ & $82.54 \pm 6.47$ \\
\hline & Administrative unit & $41.43 \pm 3.37$ & $21.29 \pm 2.24$ & $17.67 \pm 4.21$ & $80.38 \pm 6.62$ \\
\hline & Clinic & $42.78 \pm 2.84$ & $21.35 \pm 2.23$ & $17.09 \pm 2.33$ & $81.22 \pm 5.35$ \\
\hline & Laboratory & $43.46 \pm 2.93$ & $21.23 \pm 2.8$ & $18.38 \pm 3.59$ & $83.08 \pm 7.47$ \\
\hline & Radiological unit & $40.7 \pm 2.91$ & $22.5 \pm 2.64$ & $16.5 \pm 1.65$ & $79.7 \pm 3.56$ \\
\hline & Surgery room & $44.14 \pm 3.42$ & $21.93 \pm 2.7$ & $16.93 \pm 1.9$ & $83.0 \pm 5.55$ \\
\hline & Other & $45.0 \pm 9.21$ & $23.50 \pm 4.28$ & $20.13 \pm 4.36$ & $88.63 \pm 17.44$ \\
\hline & $\mathrm{F}$ & 1.935 & 1.267 & 1.977 & 1.948 \\
\hline & $p$ value & 0.067 & 0.270 & 0.061 & 0.065 \\
\hline \multirow{4}{*}{$\begin{array}{l}\text { Involving in the night } \\
\text { shift at the unit }\end{array}$} & Yes & $43.36 \pm 3.86$ & $21.64 \pm 2.56$ & $17.3 \pm 3.3$ & $82.3 \pm 7.56$ \\
\hline & No & $41.66 \pm 3.03$ & $21.3 \pm 2.13$ & $16.8 \pm 2.57$ & $79.75 \pm 4.77$ \\
\hline & $\mathrm{F}$ & -2.651 & -0.809 & -0.927 & -2.099 \\
\hline & $p$ value & 0.009 & 0.419 & 0.355 & 0.037 \\
\hline
\end{tabular}

Data are shown as mean \pm standard deviation. 
\pm 7.03. Lower total mean scores from the scale indicate that healthcare professionals do not use these materials in a safe manner. Higher scores, on the other hand, suggest that the materials are used safely by healthcare professionals.

Table 4 presents a comparison of the scores of the participants from the attitude scale about the safe use of sharp objects and instruments based on the following variables: age, gender, marital status, educational background, occupation, the unit they work at and night shift. Of these variables, the age, gender, marital status, educational background and occupation were found to have no statistically significant difference in the scores of the participants on the subdimensions of cognitive, affective and behavioral as well as on the total score $(p>0.05)$. It is found that the variable of the unit where the participants working athad also no statistically significant difference in the scores of the participants on the subdimensions of cognitive, affective and behavioral as well as on the total score $(p>0.05)$. However, the scores of those participants who had night shifts had statistically significantly higher scores from the cognitive subdimension $(p=0.009 ; p<0.01)$. Their total score was also found to be statistically higher than those who did not have night shifts $(p=$ 0.037; $p<0.05)$.

\section{DISCUSSION}

The CDC reported that nearly 5.6 million healthcare staff has a risk of infections contacted with bloodborne [16]. In the study, it was found that 57 (32.9\%) participants experienced either injuries caused by sharp objects and instruments and/or contact with blood or body fluid in the last year. It was also found that $18.2 \%$ of the healthcare professionals sampled had an injury caused by a sharp object or instrument in the last year $(n=32)$ (See Table 1). In the study by Omac et al. [17], it was found that the $62.7 \%$ of the nurses who participated in the study experienced at least one injury caused by a sharp instrument in the last three months. Dikmen et al. [9] found that $63.4 \%$ of the healthcare professionals (664 people) had injury due to the sharp objects and instruments at least once during their professional life and that $64.4 \%$ of them contacted with blood, body fluid and secretions at least once during their professional life. Altiok et al. [18] concluded that $79.1 \%$ of the healthcare professionals experience injuries caused by sharp instruments and that $60.9 \%$ of such injury cases occur due to the contact with an object which became entangled in blood. One of the major causes of injuries is reported to be injector needles [18]. Ottino et al. [19] state that most of the injuries occur due to the use of standard needles. Güney et al. [20] analyzed the work by healthcare professionals in the emergency unit and found that 105 of the participants had an injury caused by a sharp instrument in the last year $(32.2 \%)$. Taşçı̆ı̆lu [21] concluded that in the last six months, $56.6 \%$ of the participants experienced an occupational accident and among these accidents, the most frequent one was the injuries caused by a sharp instrument (43 participants$43.4 \%$ ). Samancioğlu et al. [22] found that $65.8 \%$ of the emergency unit nurses had one or three injury incidents caused by a sharp instrument in the last twelve months. Bush et al. [16] concluded that pathogens contaminated through contact with blood occur in the form of percutaneous injuries. It was also reported in the same study that the rate of percutaneous injuries among healthcare staff sampled varies between $74.2 \%$ and $92.3 \%$. The findings of the study also indicated that the most frequently injured groups were medical students and nurses. It may be a result of the fact that nurses frequently involve in medical practices. In short, Bush et al's study [16] suggests that there is a close relationship between occupational experience and the rate of injuries. However, the current study does not focus on the correlation between occupational experience and the rate of injuries.

In the present study, the majority of the participants experienced the injuries during taking the medicine from a vial $(21.1 \%, \mathrm{n}=12)$. It was followed during the case of separating the needle from an injector $(15.8 \%, \mathrm{n}=9)$ and during the recapping of the needle $(8.8 \%, \mathrm{n}=5)$ (See Table 1$)$. The related studies similarly indicate that the injury cases occur during the preparation of materials or recapping of needle [23].

In the study, it was also found that the majority of the participants did not report any injury cases $(79 \%)$ (See Table 2). Of those who reported such incidents, $75.7 \%$ were found to report the incident to infection 
control nurses $(\mathrm{n}=28), 24.3 \%$ of these participants reported it to the occupational health and safety unit $(\mathrm{n}=9)$, and $18.9 \%$ of them reported the incidents to the unit responsible $(\mathrm{n}=7)$. Samancioğlu et al. [22] concluded thatin the case of injuries caused by sharp instruments, $80 \%$ of the nurses sampled reported the incident to infection control nurse. Akkaya et al. [24] concluded that 32 of the nurses reported such incidents to the infection control committee.

The total mean score of the participants from the scale was found to vary between 68 and 112 with a mean of $81.65 \pm 7.03$ (See Table 3). Özyiğit et al. [25] found that the total mean score of the participants from the same scale was $84.21 \pm 5.23$ (min: 68 - max:110). In the study, some of the variables (namely, age, gender, marital status, educational background and occupation) were found to have no statistically significant effect on the scores of the participants from the attitude scale about the safe use of sharp objects and instruments (see Table 4). Their specific occupation did not affect the total scores and subdimension scores in a statistical manner. In the study of Özyiğit et al. [25], no significant difference was found in the scores of the nurses, physicians and other healthcare staff who participated from the cognitive section of the scale. However, the behavioral mean scores of the nurses $(20.09 \pm 2.71)$ were higher than those of the physicians $(19.12 \pm 2.08)$ and cleaning staff members $(19.14 \pm 2.10)$. Another interesting finding of the study was that although it was not statistically significant, the scores of the physician's samples from the cognitive subdimension of the scale were higher than those of the other participants, but their scores from the behavioralsubdimension were the lowest. Özyiğit et al. [25] similarly concluded that the physicians sampled in their study had the lowest behavioral scores. Therefore, it can be argued that physicians do not pay much attention to the necessary behaviors in using sharp medical instrumentsand that they perceive their working conditionsless risky. Given that, inservice training activities at hospitals mostly address nurses and other auxiliary healthcare staff and it can be stated that physicians have lower levels of awareness about the potential occupational accidents. Therefore, in-service training activities should be attended by all healthcare staff at hospitals.

\section{CONCLUSION}

The participants of the study are subject to serious occupational accidents and occupations risks which may negatively affect their health. In the last year, the participants mostly experienced either an injury caused by sharp instruments orcontact with blood. Such occupational accidents were mostly experienced by nurses and midwives. The injuries are experienced during the preparation of materials and the injection needles. Therefore, it is suggested that safe medical instruments should be used to avoid and reduce the potential occupational accidents, that personal protective environment should be provided by the healthcare institutions as well as the safe medical instruments should be easily accessed and that common steps should be taken and strictly followed to avoid the contact with the infection. In the study, it is revealed that not all occupational accidents are reported by the healthcare staff. Therefore, necessary steps should be taken to improve the rate of such reports which should contain the type of injury and the cause of the injury. In order to maintain a systematic reporting, there should be standard procedures.

\section{Conflict of interest}

The authors disclosed no conflict of interest during the preparation or publication of this manuscript.

\section{Financing}

The authors disclosed that they did not receive any grant during conduction or writing of this study.

\section{Authors' Contribution}

All of the authors have contributed to the study on conception and design, drafting the article, revising it critically for important intellectual content, and final approval of the version to be published. All authors are in agreement with the content of the manuscript. SÖ = Study design, data collection and preparation manuscript; VÜ = Thesis advisor, Study design and preparation manuscript.

\section{Acknowledgement}

We would like to thank all staff who gave their time and made this study possible. We would like to thank Ayca Pamukcu who did statistical analysis. 


\section{REFERENCES}

1. İnci Eİ, Bilișli Y, Hizay D. [Assessment of notifications by healthcare staff suffering from occupational accidents: case of university hospital]. Health Care Acad J 2016;3:83-8. [Article in Turkish]

2. Salman E, Karahan ZC. [Infection risks for healthcare workers and protection I: infections transmitted by blood and body fluids] Ankara Üniversitesi Tıp Fakültesi Mecmuası 2014;67:43-9. [Article in Turkish]

3. Goniewicz M, Włoszczak-Szubzda A, Niemcewicz M, Witt M, Marciniak-Niemcewicz A, Jarosz MA. Injuries caused by sharp instruments among healthcare workers -- International and Polish Perspectives. Ann Agric Environ Med 2012;19:523-7.

4. Ministry of Health, Health Statistics 2015. http://www.sagem.gov.tr/dosyalar/SIY_2015_Haber_Bulteni.pdf, Accessed: February 10, 2017.

5. Meydanlıŏ̆lu A. [Health and safety of healthcare workers]. Balıkesir Sağlık Bilimleri Dergisi 2013;2:192-9. [Article in Turkish]

6. Ndejjo R, Musinguzi G, Yu X, Buregyeya E, Musoke D, Wang $\mathrm{J}-\mathrm{S}$, et al. Occupational health hazards among healthcare workers in Kampala, Uganda. J Environ Public Health 2015;2015:913741.

7. Andersen LL, Clausen T, Mortensen OS, Burr H, Holtermann A. A prospective cohort study on musculoskeletal risk factors for long-term sickness absence among health care workers in elder care. Int Arch Occup Environ Health 2012;85:615-22.

8. Swetharani K, Vinod KV, Hamide A, Dutta TK, Harichandrakumar KT. Awareness of blood-borne infections and burden of occupational exposures to blood and body fluids among healthcare personnel in a tertiary care teaching hospital. Indian J Occup Environ Med 2016;20:138-43.

9. Dikmen AU, Medeni V, Uslu I, Aycan S. [Assessment of work accidents in health care workers in a university hospital in Ankara]. Türk Tabibler Birliği Mesleki Sağlık ve Güvenlik Dergisi 2014;14:22-8. [Article in Turkish]

10. Puro V, De Carli G, Cicalini S. European occupational postexposure prophylaxis study group. European recommendations for the management of healthcare workers occupationally exposed to hepatitis B virus and hepatitis C virus. Euro Surveill 2005;10:260-4.

11. Westermann C, Claudia Peters C, Lisiak B, Lamberti M, Nienhaus A. The prevalence of hepatitis $\mathrm{C}$ among healthcare workers: a systematic review and meta-analysis. Occup Environ Med 2015;72:880-8.

12. Ucak A. Saglık personelinin maruz kaldığı iş kazaları ve geri bildirimlerinin değerlendirilmesi. Afyon Kocatepe University Institute of Health Sciences Master Thesis, Afyonkarahisar, 2009. 13. Centers for Disease Control and Prevention. National Institute for Occupational Safety and Health.Guidelines for Protecting the Safety and Health of HealthCare Workers. https://www.cdc.gov/niosh/docs/88-119/pdfs/88-119.pdf
Accessed April 17, 2017.

14. [Regulation on the ensuring the safety of patients and employees]. Official Gazette Issue: 27897, 6 April 2011. [Article in Turkish]

15. Uzunbayır N. [An attitude scale towards safe medical device usage of healthcare workers]. Ege University, Graduate School of Health Sciences, Master Thesis, 2009. [Article in Turkish] 16. Bush C, Schmid K, Rupp ME, Watanabe-Galloway S, Wolford B, Sandkovsky U. Blood borne pathogen exposures: difference in reporting rates and individual predictors among healthcare personnel. Am J Infect Control 2017;45:372-6.

17. Omac M, Eğri M, Karaoğlu L. [Evaluation of occupational needle stick - Sharp injuries and status of Hepatitis B immunization on nurses working at Malatya province hospitals]. İnönü Üniversitesi Tıp Fakültesi Dergisi 2010;17:19-25. [Article in Turkish]

18. Altıok M, Kuyurtar F, Karaçorlu S, Ersöz G, Erdoğan S. [Healthcare workers experiences with sharps and needlestick injuries and precautions they took when injuring]. Maltepe Üniversitesi Hemşirelik Bilim ve Sanatı Dergisi 2009;2:70-9. [Article in Turkish]

19. Ottino MC, Argentero A, Argentero PA, Garzaro G, Zotti CM. Needlestick prevention devices: data from hospital surveillance in Piedmont, Italy-comprehensive analysis on needlestick injuries between healthcare workers after the introduction of safety devices. BMJ Open 2019;9:2-10.

20. Güney SB, Köksal O, Durak VA. [The needlestick and sharp injuries among emergency service workers and analysis of prevention methods]. Uludağ Üniversitesi Tıp Fakültesi Dergisi 2017;43:1-5.

21. Taşçığlu I. [To fix the risks which arise from work and working environment and the level of nurses' perception of these risks in Lüleburgaz state Hospital and Lüleburgaz 82. Yil State Hospital]. Trakya University, Faculty of Health Science, Master Thesis, Edirne, 2007. [Article in Turkish]

22. Samancioğlu S, Unlu D, Akyol AD. [The evaluation of needlestick and sharp injuries among intensive care nurses]. Anadolu Hemşirelik ve Sağlık Bilimleri Dergisi 2013;16:43-9. [Article in Turkish]

23. Motaarefi H, Mahmoudi H, Mohammadi E, HasanpourDehkordi A. Factors associated with needlestick injuries in healthcare occupations: a systematic review. J Clin Diagn Res 2016;10:IE01-04.

24. Akkaya S, Sengoz G, Pehlivanoğlu F, Özdemir EG, Tek SA. [Evaluation of the survey results concerning sharps injuries]. Klimik Dergisi 2014;27:95-8. [Article in Turkish]

25. Özyiğit F, Küçük A, Altuntaş Ö, Arıkan İ, Kumbasar H, Fener $\mathrm{S}$, et al. [The attitude of healthcare workers to safe use of medical instruments in a training and research hospital]. Med Bull Haseki 2014;52:168-71. [Article in Turkish] 